DOI: https://doi.org/10.32839/2304-5809/2021-4-92-67

УДК 336.5.02

Синютка Н.Г., Курило О.Б., Москалюк С.В.

Національний університет «Львівська політехніка»

\title{
ЕВОЛЮЦІЯ ПУБЛІЧНИХ ЗАКУПІВЕЛЬ В УКРАЇНІ
}

\begin{abstract}
Анотація. У статті розглянуто ринок публічних закупівель, його структуру та динаміку, проаналізовано вплив електронної системи державних закупівель «Рrozorro» на рівень заощадження бюджетних коштів у державному секторі економіки України в умовах глобальної діджиталізації. Об'єктом дослідження є структура ринку державних закупівель, еволющія розвитку сектору публічних закупівель, суми заощаджень при публічних закупівлях через електронну систему закупівель «ProZorro» в Україні. Авторами означено можливості моніторингу електронної системи публічних закупівель як окремого інструменту бюджетної політики. Зокрема, розглянуто напрямки впливу діджиталізації на ефективність ринку державних закупівель та досліджено розвиток державної системи електронних закупівель “ProZorro» в Україні в умовах прозорості та діджиталізації сектору публічних закупівель.
\end{abstract}

Ключові слова: державні видатки, тендер, публічні закупівлі, платформа електронних закупівель «ProZorro», бюджетні кошти.

\section{Synyutka Nataliya, Kurylo Oksana, Moskaliuk Sviatoslav Lviv Polytechnic National University}

\section{EVOLUTION OF PUBLIC PROCUREMENT IN UKRAINE}

Summary. The article considers the dynamics and structure of the public procurement market, analyzes the impact of the electronic public procurement system "Prozorro" on the level of budget savings in the public sector of Ukraine's economy in the context of global digitalization. It is stated that as a result of the functioning of the public procurement system, the state satisfies public needs in goods, jobs, services, as well as provides funding for the activities of budgetary institutions. For the business sector, public procurement is an opportunity to diversify the market. If government expenses remain a low-grade tool for government intervention, then budgets can demonstrate deficiency at any level of tax revenues. Effective functioning of the public procurement system in conditions of modern economic transformations allows to solve a number of social and economic problems of the state, provides carrying out of scientific researches, creation and introduction of new technologies and developments. The object of the study is the analysis of the volume and structure of the public procurement market, the number of procedures and bidders, the amount of savings in public procurement "ProZorro" in Ukraine. The authors identify the possibilities of monitoring the electronic system of public procurement as a separate tool of budget policy. Introduction of e-procurement systems at the state level gradually increases the competitiveness of the environment, reduces the loss of customers from insufficient competition in public goods markets, promotes the development of small and medium-sized businesses, including local companies and small local enterprises. The introduction of a modern system of electronic public procurement ensures their maximum openness and optimization of public spending, minimization of costs and reduction of installation time, improving the quality and reliability of decisions on the execution of contracts. In particular, the directions of the impact of digitalization on the transparency and efficiency of the public procurement market are considered and the development of the state system of electronic procurement "ProZorro" in Ukraine in terms of innovative digital direction is studied.

Keywords: public expenditures, tender, public procurement, ProZorro, e-procurement platform, budget funds.

Постановка проблеми. Платформа 1 публічних електронних закупівель «ProZorro» $е$ важливим інструментом впливу на обсяги та напрямки державних видатків. Доцільне використання державних коштів на стратегічні потреби, забезпечення прозорості та боротьба з корупціею на сьогодні є одними 3 головних пріоритетів державної фріскальної політики України. Порушення ефективного функціонування публічного сектору економіки часто тягне за собою дефіцит бюджетних коштів в незалежності від рівня податкових надходжень. В сучасних умовах фінансової кризи, яка $е$ наслідком світової пандемії, спровокованої SARS-CoV-2, економія бюджетних видатків $\epsilon$ важливою для діяльності кожної держави світу, оскільки в умовах карантинних обмежень, скорочення зайнятості населення та скорочення діяльності суб'єктів підприємницької діяльності бюджетні надходження зменшуються, а державні видатки, особливо у сфері охорони здоров'я, постійно зростають. Зекономлені кошти зараз особливо необхідні для діяльності країни.

Метою цифровізації у цьому секторі е посилення конкурентності тендерів, встановлення дієвого державного контролю над витрачанням бюджетних коштів та ресурсів державних компаній, недопущення недобросовісних практик та скорочення корупщійної ренти.

Інформаційні технології та діджиталізація стали ключовими чинниками для реформи публічних закупівель в Україні та світі. Запровадження єдиної централізованої електронної системи закупівель може створювати як нові ринки товарів i послуг, так і розширювати існуючі, впливати на витрати і споживання економічних суб’ектів, покращувати якість продукції в системі суспільного споживання, змінювати структуру та формат пра- 
ці, збільшувати зайнятість, стимулювати впровадження інновацій та нових технологій тощо.

Цифровізація публічного сектору економіки оптимізуе процес управління доходами та видатками бюджету, може знижувати адміністративний тягар та підвищувати рівень прозорості публічного управління.

Аналіз останніх досліджень і публікацій. Питання особливостей здійснення публічних закупівель $є$ предметом розгляду та тривалих наукових дискусій зарубіжних та вітчизняних вчених. Науковцями, які розглядають проблематику державних закупівель є: Критенко О.О., Левченко С.Ю., Малолітнева В.К., Науменко С.М., Олефрip А.О., Смиричинський В.В., Ткаченко Н.Б., Фалко Ю.В. Попри значні дослідження сорери публічних закупівель та суспільного споживання, залишаються недостатнњо обгрунтованими питання щодо ефективності заощадження бюджетних видатків.

Постановка завдання. Дослідити еволюцію ринку публічних закупівель в Україні. Зокрема, економічні ефректи від імплементащії електронної системи державних закупівель ProZorro, оці-

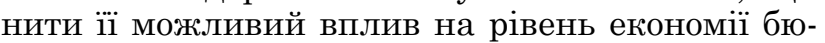
джетних коштів в державному секторі. Об'єктом дослідження $є$ аналіз обсягу та структури ринку державних закупівель, кількості процедур та учасників торгів, а також суми економії у державних закупівлях упродовж досліджуваного періоду 2016-2020 років в Україні.

Виклад основного матеріалу дослідження. Однією з найуспішніших реформ, яка здобула підтримку як серед українців, так і з боку міжнародного співтовариства, є реформа публічних закупівель. Новаторство полягало у переході на електронну систему "ProZorro». Система електронних закупівель «ProZorro» дозволяе відкрито слідкувати за державними і комерційними аукціонами, проводити аналіз ринку, контролювати державні закупівлі, отримувати інформацію про тендери. Від початку переходу піблічних закупівель на цю систему експерти неодноразово наголошували на тому, що завдяки використанню «ProZorro» в copepi державних закупівель вдається зекономити бюджетні кошти.

Публічні закупівлі - це придбання замовником товарів, робіт і послуг у порядку, встановленому Законом України "Про публічні закупівлі". Виділяють три стадії процесу публічних закупівель:

- ідентифікація потреби, прийняття рішення щодо того, які товари, роботи або послуги мають бути придбані і коли (планування закупівель);
- процес розміщення оголошення про закупівлю відповідних товарів, робіт або послуг, кваліфікацію постачальника (включаючи аукціон для конкурентних процедур) та підписання договору;

- процес адміністрування договору.

Головними перевагами електронної системи є економія коштів та часу, мобільність, можливість доступу до системи з будь-якої країни, рівні умови для усіх учасників і відсутність паперової тяганини.

Система «ProZorro» - завдяки відкритому доступу до моніторингового процесу проведення тендерів - унеможливлюе корупційні схеми у сорері державних закупівель. Усі закупівлі державних компаній, установ і органів влади проводяться тільки через електронну систему «ProZorro». Електронна система закупівель побудована таким чином, що ні держава, ні адміністратор системи не можуть здійснювати вплив на учасників процедури закупівлі та будь-яким чином відсіювати їх.

Варто зазначити, сорера державних закупівель в Україні регулюеться Законом України «Про здійснення державних закупівель» та законом «Про публічні закупівлі». Згідно з Законом України "Про публічні закупівлі" портал «ProZorro» є відкритим ресурсом, який надає доступ до усіеї інформації з центральної бази даних про цифрові тендерні аукціони, що були оголошені з 31 липня 2016 року. Порушення у сфрері державних закупівель фріксується Держказначейством та Антимонопольним комітетом.

Будь-яка хто, представник ЗМІ чи контролюючий орган завдяки «ProZorro» можуть бути віртуально присутніми на аукціоні-закупівлі. Система назавжди зберігає історію редагувань та дає можливість подивитись видалені документи. Спроба провести корумпований тендер одразу отримуе розголос.

Ha 01.01.2021 року у системі «ProZorro» 50890 оголошених тендерів та 123912 активних постачальників. За 5 років існування система Prozorro зекономила 163 млрд гривень бюджетних коштів. Це різниця між тим, за скільки очікували замовники закупити послуги чи товари, і за скільки закупили в результаті конкуренції між постачальниками. Адже останні на торгах знижували ціни на роботи та послуги 3 метою отримання бюджетного замовлення. Тож лише у 2020 р було зекономлено найбільше коштів: понад 43 мільярди гривень. Приходимо до висновку, що едективність публічних закупівель зростає із року в рік.

Аналіз ринку публічних закупівель в Україні у 2016-2020 рр.

Таблиця 1

\begin{tabular}{|c|c|c|c|c|c|c|}
\hline & $\begin{array}{c}\text { Очікувана } \\
\text { вартість } \\
\text { оголошених } \\
\text { тендерів, } \\
\text { млрд. грн }\end{array}$ & $\begin{array}{c}\text { Сума } \\
\text { укладених } \\
\text { договорів, } \\
\text { млрд. грн }\end{array}$ & $\begin{array}{c}\text { Кількість } \\
\text { тендерів, } \\
\text { тис. шт. }\end{array}$ & $\begin{array}{c}\text { Кількість } \\
\text { організаторів, } \\
\text { шт. }\end{array}$ & $\begin{array}{c}\text { Кількість } \\
\text { учасників, } \\
\text { тис. }\end{array}$ & $\begin{array}{c}\text { Економія, } \\
\text { млрд. грн. }\end{array}$ \\
\hline 2016 & 129,10 & 70,28 & 3,95 & 680 & 3,72 & 3,5 \\
\hline 2017 & 332,42 & 204,03 & 9,06 & 682 & 6,72 & 11,55 \\
\hline 2018 & 330,80 & 178,50 & 10,67 & 701 & 6,91 & 7,98 \\
\hline 2019 & 349,83 & 179,37 & 9,98 & 676 & 6,84 & 12,13 \\
\hline 2020 & 392,89 & 229,60 & 10,21 & 635 & 7,24 & 17,62 \\
\hline Загалом & 1535,04 & 861,78 & 43,87 & 3374 & 31,43 & 52,78 \\
\hline
\end{tabular}

Джерело: розроблено авторами за даними [2; 9] 


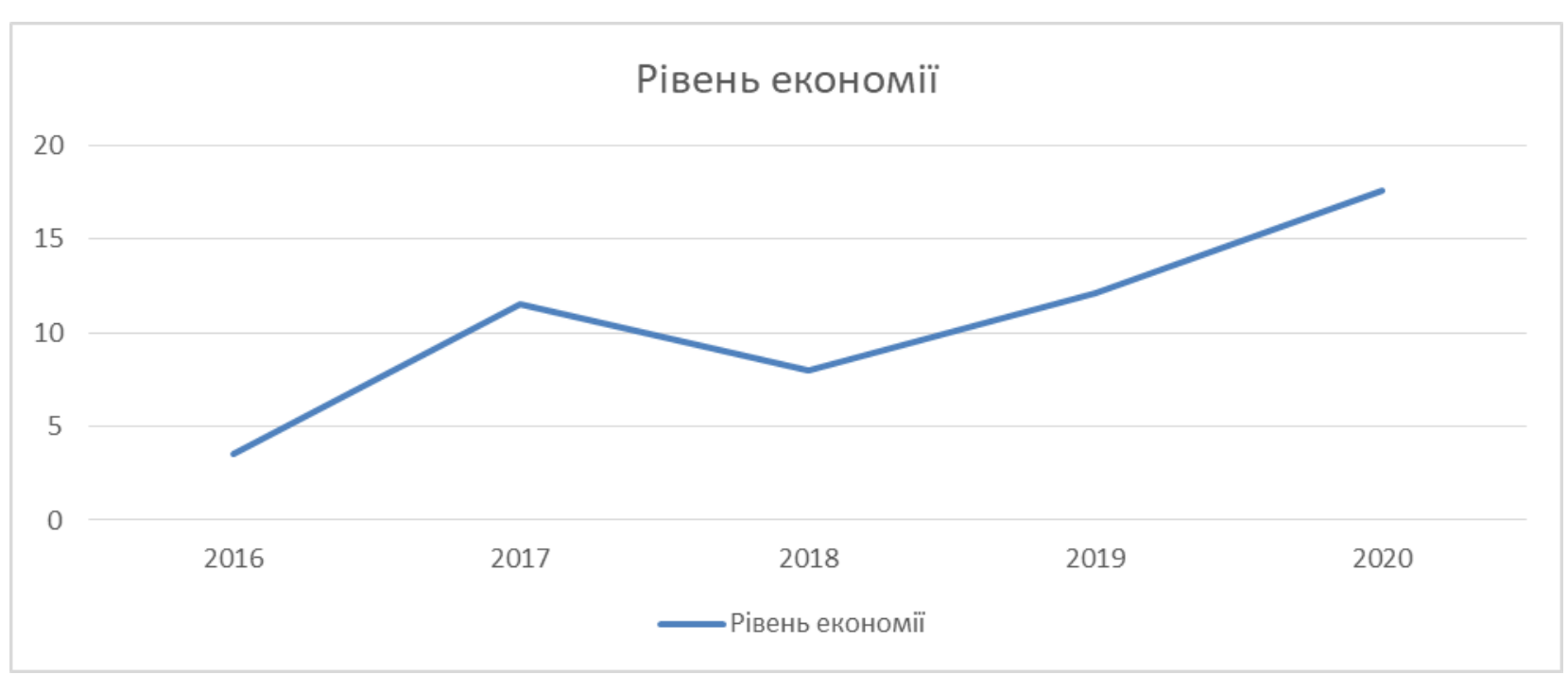

Рис. 1. Рівень економї коштів за рахунок публічних закупівель в Україні упродовж 2016-2020 рр., \%

Джерело: розроблено авторами за даними [2; 9]

Оскільки можемо бачити 3 таблищі 1 та рисунку 1 середній рівень економії за період 2016-2020 роки постійно зростае, за виключенням 2018 року. Загалом від початку реформи він складае $10,56 \%$, тобто можемо впевнено сказати, що реформа допомогла зберегти більше 10 відсотків бюджетних коштів.

Кожного року покращуеться не лише електронні платдорми через які проходить співпраця між замовниками і постачальниками, а й саме законодавство, залишаючи все менше можливостей для корупщійних маніпулящій серед учасників публічних закупівель. У минулому році сектор публічних закупівель отримав наступний важливий поштовх. Ним стали зміни до Закону України "Про публічні закупівлі", які почала діяти із 19 квітня 2020 року.

Нова редакція Закону націлена на виправлення прогалин у законодавстві, якими користувались недобросовісні замовники, та збільшення ефективності закупівель. Обмеження суми допорогових закупівель вже дозволило бюджетам різних рівнів заощадити понад 1,7 млрд грн на закупівлях, які б до цього віддавалися напряму самостійно обраному постачальнику.
Зокрема, був знижений обов'язковий поріг для закупівель через «Prozorro» до 50 тисяч гривень. До 19 квітня минулого року в рамках допорогових торгів (200 тис. грн для товарів і послуг, i 1,5 млн грн для робіт) державні замовники могли підписувати договори з самостійно обраним постачальником.

Одним з ключових напрямків реформи було збільшення рівня конкурентності у публічних закупівлях, оскільки майже половина тендерів відбувалася за участі одного учасника. Середня кількість учасників тендеру у публічних закупівлях становить лише 2,32 .

Окрім реалізації нового Закону, пришвидшуеться курс на діджиталізацію закупівель. Відбулась інтеграція Прозорро з базою даних Державної казначейської служби України, щоб зробити відкритою всю інформацію про оплати, а бізнес мав можливість перевірити своєчасність розрахунків замовників із контрагентами. Відбулася синхронізація також з базами даних АМКУ, щоб замовники ідентифікували та могли відмовляти у підписанні договору суб’ектам господарювання, які були помічені та покарані за маніпуляції

\section{Середній \% економії}

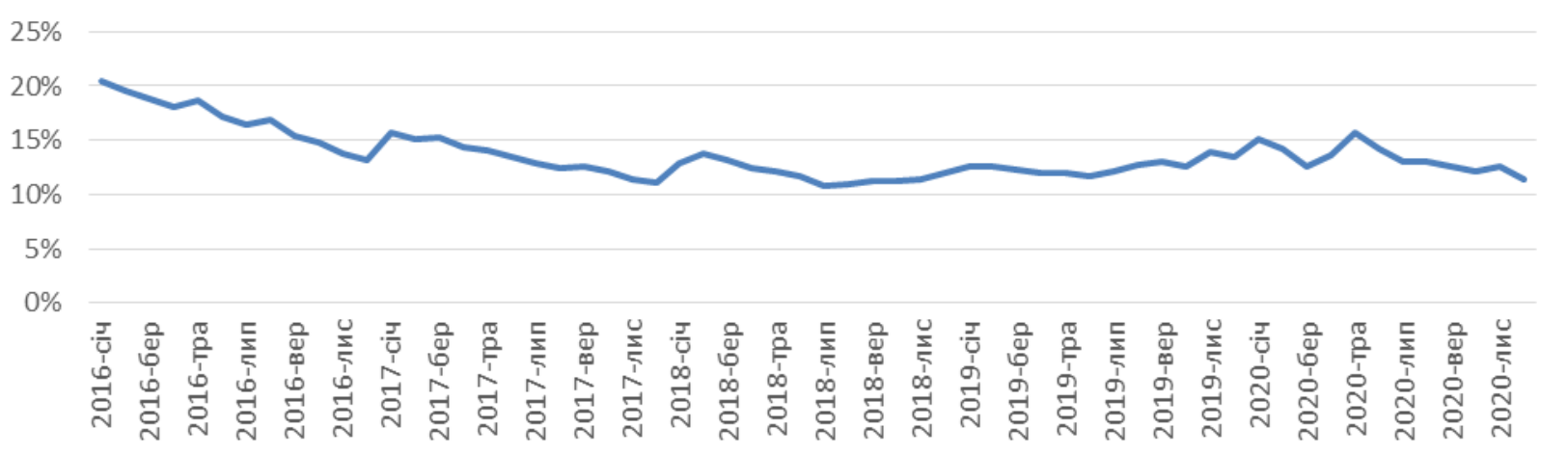

Рис. 2. Середній відсоток економії коштів у публічних закупівлях в Україні

Джерело: розроблено авторами за даними [2; 9] 
у порушенні конкуренції на торгах. Також замовники та бізнес вже вказують індормацію про свою відповідність критеріям доброчесності на електронних полях системи Prozorro.

У 2020 році за допомогою електронної системи закупівель "Prozorro" бюджети різних рівнів змогли зекономити понад 2506 млн грн, в тому числі 2271 млн грн за рахунок тендерних процедур та 236,5 млн грн - за рахунок конкурентних допорогових закупівель.

Наприклад, до регіонів, що змогли зекономити найбільшу суму бюджетних коштів, можна віднести Київську, Львівську, Харківську, Одеську та Дніпропетровську області. Це можна пояснити тим, що у Київській області знаходяться центральні офріси багатьох розпорядників бюджетних коштів, а у інших областях - їхні регіональні представництва. Розглянемо детальніше Львівську область. За даними Департаменту економічної політики ЛОДА середній показник економії в публічних закупівлях склав $12,4 \%$. У минулому році було проведено понад 186 тисяч закупівельних процедур серед 2423 замовників. На ринку публічних закупівель Львівщини працювало понад 23 тисячі учасників, серед яких лише 56\% - підприємці області. Середня конкуренція становила 2,24 учасники на торги. Якщо порівнювати 32019 роком, загальна кількість публічних закупівель зросла на 68\%, що стало додатковою можливістю розширити ринок збуту для бізнесу в умовах пандемії SARS-CoV-2. За рік бюджети області змогли заощадити 2,5 млрд. гривень. Слід зазначити, що загалом, від початку реформування сектору публічних закупівель, Львівщина змогла зекономити 8,69 млрд гривень бюджетних коштів - табл. 2.

За понад 5 років від початку редорми прозорі аукціони в держзакупівлях стали для України даністю. Але позитивний ефрект від Prozorro для української економіки лише зростає. Силу прозорості теж не варто недооцінювати. Завдяки розголосу, піднятому громадськістю та медіа, вдалося скасувати не одну скандальну закупівлю. Прозора система закупівель може слугувати не тільки медіа, а й контролюючим органам як джерело інформащії про зловживання. Слід наголосити, що новий Закон передбачив суворі покарання за грубі порушення тендерного законодавства - деякі 3 них передбачають штрафи до 170 тис. грн для керівника установи.

Зараз керівництво ДП «ProZorro» намагається тісно взаємодіяти з Державною аудиторською службою України з метою підсилення контролю у сфері закупівель. Хоча погляди щодо того, що можна вважати ефективним контролем, поки що різняться.
Насправді державні замовники в публічних закупівлях не стільки здійснюють відмивання коштів, скоріше просто не зацікавлені заощаджувати їх. Навпаки, державні та комунальні структури намагаються збільшувати обсяги бюджетних видатків, а не вишукувати резерви або купити якісні товари за оптимальною ціною.

Висновки. Редрормування публічних закупівель та перехід на систему електронних закупівель "Рrozorro» стало одним з перших кроків на шляху діджиталізації державної фріскальної політики в Україні. Сервіс фрінансового обліку "ProZorro» $є$ edрективним засобом автоматизації публічних закупівель. За часи існування система публічних торгів створила поле для спілкування замовників та постачальників. Впровадження системи електронних закупівель на державному рівні сприяе протидії корупції та підвищуе конкурентоспроможне середовище, зменшуе втрати замовників від недостатньої конкуренції.

Система електронних закупівлель, що виникла внаслідок реформи державних закупівель, за роки існування перетворилася на вагомий інструмент боротьби з відмиванням коштів серед недобросовісних керівників державних та комунальних підприемств. У періоді 2016-2020 років держава зекономила 163 мільярди гривень платників податків. Також слід зазначити, що редорма створила певний пласт суб'єктів підприємницької діяльності, для яких основним джерелом доходу $е$ саме постачання товарів, надання послуг чи виконання робіт державним підприемствам.

«ProZorro» оптимізує процес державних закупівель за рахунок збільшення швидкості операцій, зменшує адміністративне навантаження та збільшуе інноваційну складову процесу. Попри це, платформа ProZorro потребує аналізу та вдосконалення. У державних закупівлях залишаються проблеми: брак навичок та досвіду організаторів у здійсненні тендерної процедури; висока частка неконкурентних процедур (у середньому лише 2,3 пропозицій на одну закупівлю), прихований конфлікт інтересів учасників, необгрунтоване розтягування в часі окремих процедур, наприклад, адміністративного оскарження.

Електронна система державних закупівель зменшуе корупщію та бюрократизм у сорері державних закупівель, збільшуе едективність, передбачуваність та прозорість управління, покращуе використання державних ресурсів, економить бюджетні кошти та покращуе доступ для учасників процесу торгів шляхом інклюзї інноваційних цифрових технологій.

Таблиця 2

Сума заощаджених коштів місцевих бюджетів в Україні: регіональний зріз, млрд грн

\begin{tabular}{|l|c|c|c|c|c|}
\hline \multicolumn{1}{|c|}{ Регіони України } & $\mathbf{2 0 1 6}$ & $\mathbf{2 0 1 7}$ & $\mathbf{2 0 1 8}$ & $\mathbf{2 0 1 9}$ & $\mathbf{2 0 2 0}$ \\
\hline Київська обл. & 7,21 & 14,59 & 15,63 & 9,92 & 20,30 \\
\hline Львівська обл. & 0,49 & 1,76 & 1,43 & 2,5 & 2,85 \\
\hline Харківська обл. & 0,32 & 1,06 & 1,49 & 1,89 & 2,58 \\
\hline Дніпропетровська обл. & 0,64 & 1,61 & 1,39 & 2,26 & 5,66 \\
\hline Одеська обл. & 0,96 & 1,16 & 0,85 & 0,96 & 1,53 \\
\hline
\end{tabular}

Джерело : розроблено авторами за даними [2; 9] 


\section{Список літератури:}

1. Про публічні закупівлі : Закон України від 12.04.2016 p. №1078. URL: https://zakon.rada.gov.ua/laws/ show/922-19

2. Інформаційна система сайту Prozorro. 2020. URL: https://bi.prozorro.org/sense/app/

3. Синютка Н.Г., Курило О.Б., Василюк Т.В. ProZorro: виклики для діджиталізації державних видатків в Україні. Молодий вчений. 2021. № 1(89). С. 191-195.

4. Василюк Т.В. Прозорро як драйвер діджиталізації публічних закупівель та державних видатків в Україні. 78-ма Студентська науково-технічна конференція. Секція «Економіка і менеджмент» : збірник тез доповідей (Львів, жовтень-листопад 2020 р.). Львів, 2020. С. 238.

5. Синютка Н.Г., Василюк Т.В. Електронні публічні закупівлі ProZorro в Україні: ефект відкритих даних. Проблеми формування та розвитку інноваційної інфраструктури : матеріали V Міжнародної науково-практичної 33 конференції, Львів, 23-25 травня 2019 р. Львів : Видавництво Львівської політехніки. С. 194-195.

6. Synyutka N., Kurylo O., Vasyliuk T. Digital transformation of public procurement in Ukraine. IX Міжнародний молодіжний науковий форум "Litteris et Artibus" \& 14-та Міжнародна конференція "Молоді вчені до викликів сучасної технології" : матеріали, 21-23 листопада, 2019, Львів, Україна. Lviv : Lviv Polytechnic Publishing House. C. 177-179.

7. Міняйло O.I. Сучасний стан та перспективи розвитку електронних державних закупівель в Україні. Еконолічний вісник університету. 2016. Вип. 29(1). C. 135-144. URL: http://nbuv.gov.ua/UJRN/ecvu_2016_ $29 \% 281 \% 29 \_18$

8. Романенко Є., Щокін Р. Реформування системи державних закупівель в Україні. Публічне урядування. 2016. № 4. C. 25-34.

9. Багатогалузева статистична інформація / Регіональна статистика. Державна статистична служба України. URL: http://www.ukrstat.gov.ua/

10. Олефір А.О. Проблеми публічних закупівель крізь призму европейського досвіду. Теорія $i$ практика правознавства. 2017. Вип. 1. URL: http://nbuv.gov.ua/UJRN/tipp_2017_1_7

\section{References:}

1. On Public Procurement: Law of Ukraine dated 12.04. 2016 No. 10778. Retrieved from: https://zakon.rada.gov.ua/ laws/show/922-19 (in Ukrainian)

2. Prozorro Information System (2020) Retrieved from: https://bi.prozorro.org/sense/app (in Ukrainian)

3. Synyutka N., Kurylo O., Vasyliuk T. (2021) ProZorro: challenges for the digitalization of public spending in Ukraine. Young scientist, no. 1(89), pp. 191-195.

4. Vasyliuk T. (2020) Prozorro as a driver of digitalization of public procurement and public spending in Ukraine. 78th Student Scientific and Technical Conference. Section "Economics and Management": a collection of abstracts (Lviv, October-Nvember 2020). Lviv, p. 238.

5. Synyutka N., Vasyliuk T. (2019) ProZorro e-procurement in Ukraine: the effect of open data. Problems of formation and development of innovation infrastructure: materials of the V International scientific-practical 33 conference, Lviv, May 23-25, Lviv: Lviv Polytechnic Publishing House, pp. 194-195.

6. Synyutka N., Kurylo O., Vasyliuk T. (2019) Digital transformation of public procurement in Ukraine. IX International Youth Scientific Forum "Litteris et Artibus" \& 14th International Conference "Young Scientists to the Challenges of Modern Technology": materials, November 21-23, Lviv, Ukraine. Lviv: Lviv Polytechnic Publishing House, pp. 177-179.

7. Minyailo O.I. (2016) Current state and prospects of e-procurement development in Ukraine. Economic Bulletin of the University, vol. 29(1), pp. 135-144. URL: http://nbuv.gov.ua/UJRN/ecvu_2016_29\%281\%29_18

8. Romanenko E., Shchokin R. (2016) Reforming the public procurement system in Ukraine. Public governance, no. 4 , pp. $25-34$.

9. Multidisciplinary statistical information / Regional statistics. State Statistical Service of Ukraine. URL: http://www.ukrstat.gov.ua/

10. Olefir A.A. (2017) Problems of public procurement through the prism of European experience. Theory and practice of jurisprudence, vol. 1. URL: http://nbuv.gov.ua/UJRN/tipp_2017_1_7 